\title{
Curcumol inhibits the proliferation of gastric adenocarcinoma MGC-803 cells via downregulation of IDH1
}

\author{
SHILEI ZANG ${ }^{1 *}$, QILING TANG ${ }^{2 *}$, FANGRUI DONG ${ }^{1}$, HUAN LIU $^{1}$, LILI LI $^{1}$, FANG GUO ${ }^{1}$, XUEDIAO PAN $^{1}$, \\ HAORONG LIN ${ }^{1}$, WEIBIN ZENG ${ }^{1}$, ZHAOXU CAI $^{1}$, QIBIN ZHONG $^{1}$, NING ZANG $^{3}$ and LINQUAN ZANG ${ }^{1}$ \\ ${ }^{1}$ New Drug Screening Center, Pharmaceutical College, Guangdong Pharmaceutical University, \\ Guangzhou, Guangdong 510006; ${ }^{2}$ Xinhua College of Sun Yat-sen University, Dongguan, Guangdong \\ 523000; ${ }^{3}$ Guangzhou Nansha Central Hospital, Guangzhou, Guangdong 511400, P.R. China
}

Received March 18, 2017; Accepted August 22, 2017

DOI: $10.3892 /$ or.2017.6028

\begin{abstract}
Curcumol, a polyphenol compound derived from the rhizome of Curcuma, has been established as an antitumor compound against multiple types of cancer, including gastric (GC), lung, liver and breast cancer. However, the molecular mechanisms undelying its anticancer activity in GC are still unclear. In this study, the antitumor efficacy of curcumol was ascertained in human gastric adenocarcinoma MGC-803 cells. An MTT assay was used to assess the viability of the MGC- 803 cells treated by curcumol. The results of the Annexin V/propidium iodide (PI) staining followed by fluorescence activated cell sorting (FACS) analysis demonstrated that the cell cycle was arrested in the G2/M phase by curcumol. Annexin V-FITC/PI double staining followed by FACS analysis revealed that curcumol induced apoptosis of MGC-803 cells. FACS analysis after the cells were loaded with a DFCH-DA probe revealed that the level of reactive oxygen species (ROS) increased after the cells were treated with curcumol. In adittion, FACS analysis after the cells were loaded with JC-1 revealed that the level of mitochondrial membrane potential (MMP) decreased after the cells were treated with curcumol. Furthermore, the downregulation of isocitrate dehydrogenase 1 (IDH1) was observed in the MGC-803 cells after being treated with curcumol as determined by western blotting and RT-qPCR. In conclusion, we elucidated the antitumor effect of curcumol on MGC-803 cells and the involved mechanisms related to the
\end{abstract}

Correspondence to: Professor Linquan Zang, New Drug Screening Center, Pharmaceutical College, Guangdong Pharmaceutical University, 280 Waihuan East Road, Guangzhou Higher Education Mega Center, Panyu, Guangzhou, Guangdong 510006, P.R. China

E-mail: zanglq@163.com

*Contributed equally

Key words: gastric cancer, curcumol, reactive oxygen, isocitrate dehydrogenase, mitochondrial membrane potential induction of apoptosis, the increase of ROS, the decrease of MMP and the downregulation of IDH1.

\section{Introduction}

Gastric cancer (GC) is one of the most common malignancies around the world (1). Although its morbidity has been in decline in most developed countries in recent decades (2), GC was estimated to be the second cause of cancer-related deaths in 2015 in China (3). Surgery is the primary method of GC treatment, but it is not suitable for the majority of patients diagnosed with advanced tumors due to late diagnosis. Alternatively, chemotherapy is more suitable for these patients (4). Classical platinum-based chemotherapies provide limited improvement in survival rates and possess substantial toxicity (5). In addition, only a small percentage of patients $(20 \%)$ benefit from human epidermal receptor 2 (HER2)-targeted therapy (6-8). Therefore, the development of novel drugs to treat advanced GC patients is urgent and essential.

In the past few years, numerous natural compounds extracted from Chinese herbs have been identified to possess anti-GC activity (9-11). Curcumol, a compound first isolated from the rhizome of Curcuma by Hiroshi in 1965, has been demonstrated to be effective in tumor treatment with low cytotoxicity (12).

Our previous studies revealed that curcumol inhibited cell proliferation of SPC-A-1 human lung adenocarcinoma cells in vitro and in vivo (13). Curcumol and other ingredients isolated from Rhizoma Curcumae have been identified to induce apoptosis of GC cells and inhibit the proliferation of GC cell lines $(14,15)$. However, the underlying mechanism has yet to be fully elucidated.

In the present study, we identified the antitumor mechanisms of curcumol in GC. We ascertained the antitumor effect of curcumol on GC cells. We revealed that curcumol induced cell apoptosis and G2/M cell cycle arrest in GC cells. Moreover, the results revealed that curcumol upregulated the intracellular reactive oxygen species (ROS) level and decreased the mitochondrial membrane potential (MMP). The downregulation of isocitrate dehydrogenase 1 (IDH1) was also involved in the antitumor activity of curcumol. 


\section{Materials and methods}

Chemicals and reagents. Curcumol (racemate, purity $\geq 96.7 \%$ ) was donated by Haimen Desihang Co., Ltd. (Zhejiang, China). Curcumol was dissolved in absolute ethyl alcohol and diluted in Dulbecco's modified Eagle's medium (DMEM) culture medium with $1 \%$ alcohol to treat cells. AG-120 (ivosidenib) was purchased from Selleck Chemicals (Houston, TX, USA). Dimethyl sulfoxide (DMSO) was purchased from Aladdin Reagent Co. (Los Angeles, CA, USA). Fetal bovine serum (FBS), DMEM and Trypsin-EDTA were all purchased from Gibco (New York, NY, USA). Methylthiazolyldiphenyl-tetrazolium bromide (MTT) was purchased from Gen-View Scientific Inc. (Calimesa, CA, USA).

Annexin V-FITC Apoptosis Detection kit, Cell Cycle and Apoptosis Analysis kit, MMP assay kit with JC-1 and Reactive Oxygen Species Assay kit were purchased from Beyotime Biotechnology Co., Ltd. (Shanghai, China). A Hoechst 33258 kit was purchased from Kaiji Biotechnology Co., Ltd. (Jiangsu, China). The antibodies against IDH1, IDH2 and glyceraldehyde 3-phosphate dehydrogenase (GAPDH) were purchased from Proteintech Group, Inc. (Chicago, IL, USA). PrimeScript $^{\text {TM }}$ RT reagent kit with gDNA Eraser (Perfect Real-Time), SYBR ${ }^{\circledR}$ Premix Ex Taq ${ }^{\mathrm{TM}}$ II (Tli RNaseH Plus), RNAiso Plus and diethyl pyrocarbonate (DEPC)-treated water were purchased from Takara (Shiga, Japan). The primers of IDH1, IDH2 and GAPDH were synthesized by Sangon Biotech Co., Ltd. (Shanghai, China).

Cell culture. The human GC cell line MGC-803 and the human embryonic lung fibroblast cell line MRC-5 were purchased from the Institute of Biochemistry and Cell Biology, SIBS, of the Chinese Academy of Sciences (CAS, Shanghai, China). Both cell lines were cultured in DMEM supplemented with $10 \% \mathrm{FBS}$ at $37^{\circ} \mathrm{C}$ in a humidified atmosphere with $5 \% \mathrm{CO}_{2}$.

Assessment of viability. Cell viability was detected by MTT assay. The MGC-803 and MRC-5 cells were cultured in 96-well plates at a density of $3 \times 10^{3}$ cells $/ 100 \mu \mathrm{l} /$ well. After incubation for $24 \mathrm{~h}$, the cells were treated with: DMEM culture medium, $1 \%$ alcohol (DMEM culture medium with $1 \%$ alcohol) and curcumol at concentrations of 20,40,60, 80, 100 , and $120 \mu \mathrm{M}$ or AG-120 at concentrations of $40,60,80$ and $100 \mu \mathrm{M}$ for different time-points, including 24, 48 and $72 \mathrm{~h}$. NAC was used to detect whether curcumol inhibited cell proliferation by increasing ROS. The cells were treated with the control (DMEM culture medium), 1\% alcohol (DMEM culture medium with $1 \%$ alcohol), curcumol $(80 \mu \mathrm{M})$, NAC (5 mM), curcumol $(80 \mu \mathrm{M})+\mathrm{NAC}(5 \mathrm{mM})$ for 24,48 and $72 \mathrm{~h}$. Then $10 \mu \mathrm{l}$ of $0.5 \mathrm{mg} / \mathrm{ml}$ MTT were added to each well and the mixture was cultured at $37^{\circ} \mathrm{C}$ for an additional $4 \mathrm{~h}$. Subsequently the culture medium was replaced with $100 \mu \mathrm{l}$ DMSO to dissolve the formazan crystals. After shaking for $10 \mathrm{~min}$, the absorbance of each well was determined at $570 \mathrm{~nm}$ by a plate reader (Bio-Rad Laboratories, Inc., Hercules, CA, USA). Five replicate wells were designed for each sample. This experiment was repeated three times and the cell viability was calculated as follows: cell viability rate $(\%)=($ experimental OD value - zero set OD value)/(control OD value - zero set $\mathrm{OD}$ value) $\mathrm{x} 100$. The $50 \%$ inhibitory concentration $\left(\mathrm{IC}_{50}\right)$ was calculated by GraphPad Prism 6 (GraphPad Software Inc., La Jolla, CA, USA).

Apoptosis assay by Hoechst 33258. The MGC-803 cells in logarithmic growth phase were cultured in a 6 -well plate and treated with curcumol $(0,20,40,60,80$ and $100 \mu \mathrm{M})$ for $24 \mathrm{~h}$. Then the cells in each well were stained using Hoechst 33258 and the changes in the nuclei of cells were observed and photographed with a fluorescence microscope (Leica Microsystems, Wetzlar, Germany).

Apoptosis assays by Annexin V-FITC/PI double staining. MGC-803 cells were seeded in 6-well plates at a density of $1 \times 10^{5}$ cells/well. After being cultured with various concentrations $(0,20,40,60$ and $80 \mu \mathrm{M})$ of curcumol for $24 \mathrm{~h}$, the cells were collected and stained using an Annexin V-FITC Apoptosis Detection kit (including PI) according to the manufacturer's instructions. Then the cells were analyzed using a flow cytometer (Beckhman Coulter Inc, Brea, CA, USA).

Cell cycle distribution assay. Similar to the apoptosis assays by Annexin V/PI staining, the cells treated with curcumol for $24 \mathrm{~h}$ were collected. Then the cells were stained with PI according to the manufacturer's instructions. The cell cycle distribution was detected a the flow cytometer and was analyzed using FlowJo software (FlowJo, LLC, Ashland, OR, USA).

MMP assay. The MMP assay was performed to evaluate the level of the polarization/depolarization of the mitochondrial membrane using the JC- 1 dye. MGC- 803 cells were treated with curcumol $(0,20,40,60$ and $80 \mu \mathrm{M})$ at a density of $1 \times 10^{5}$ cells/well in a 6 -well plate. After $24 \mathrm{~h}$, the cells were collected and stained using JC-1 according to the manufacturer's instructions. Finally, the cells were analyzed on a flow cytometer and the results were analyzed using FlowJo software.

ROS assay. The ROS assay was performed to detect the intracellular ROS production from the curcumol-treated MGC-803 cells. Briefly, the cells were seeded at a density of $1 \times 10^{5}$ cells/well in a 6 -well plate and incubated for $24 \mathrm{~h}$. The cells were then treated with curcumol $(0,20,40,60$ and $80 \mu \mathrm{M}$, $\mathrm{NAC}, \mathrm{NAC}+80 \mu \mathrm{M}$ curcumol) for another $24 \mathrm{~h}$. Then the cells were loaded with DFCH-DA and harvested for the ROS assay according to the manufacturer's instructions. Finally, the assay results were analyzed on a flow cytometer and the data were analyzed using FlowJo software.

Western blot analysis. MGC-803 cells were cultured in a 6 -well plate at a density of $2 \times 10^{5}$ cells/well with different curcumol concentrations, including $0,20,40,60$ and $80 \mu \mathrm{M}$. AG-120 $(80 \mu \mathrm{M})$ treatment was used as a positive control. After $48 \mathrm{~h}$, the cells were collected in lysis buffer and incubated on ice for $20 \mathrm{~min}$. The lysates were centrifuged at $4^{\circ} \mathrm{C}$ for $20 \mathrm{~min}$ and then the supernatant was transferred to a new $1.5-\mathrm{ml}$ test tube. To ensure the equal loading of protein $(40 \mu \mathrm{g})$ for each group, protein quantification (Thermo Fisher Scientific, Waltham, MA, USA) was performed to detect the total protein. Then the samples were separated by $10 \%$ sodium dodecyl sulfate polyacrylamide gel electrophoresis (SDS-PAGE) and were 

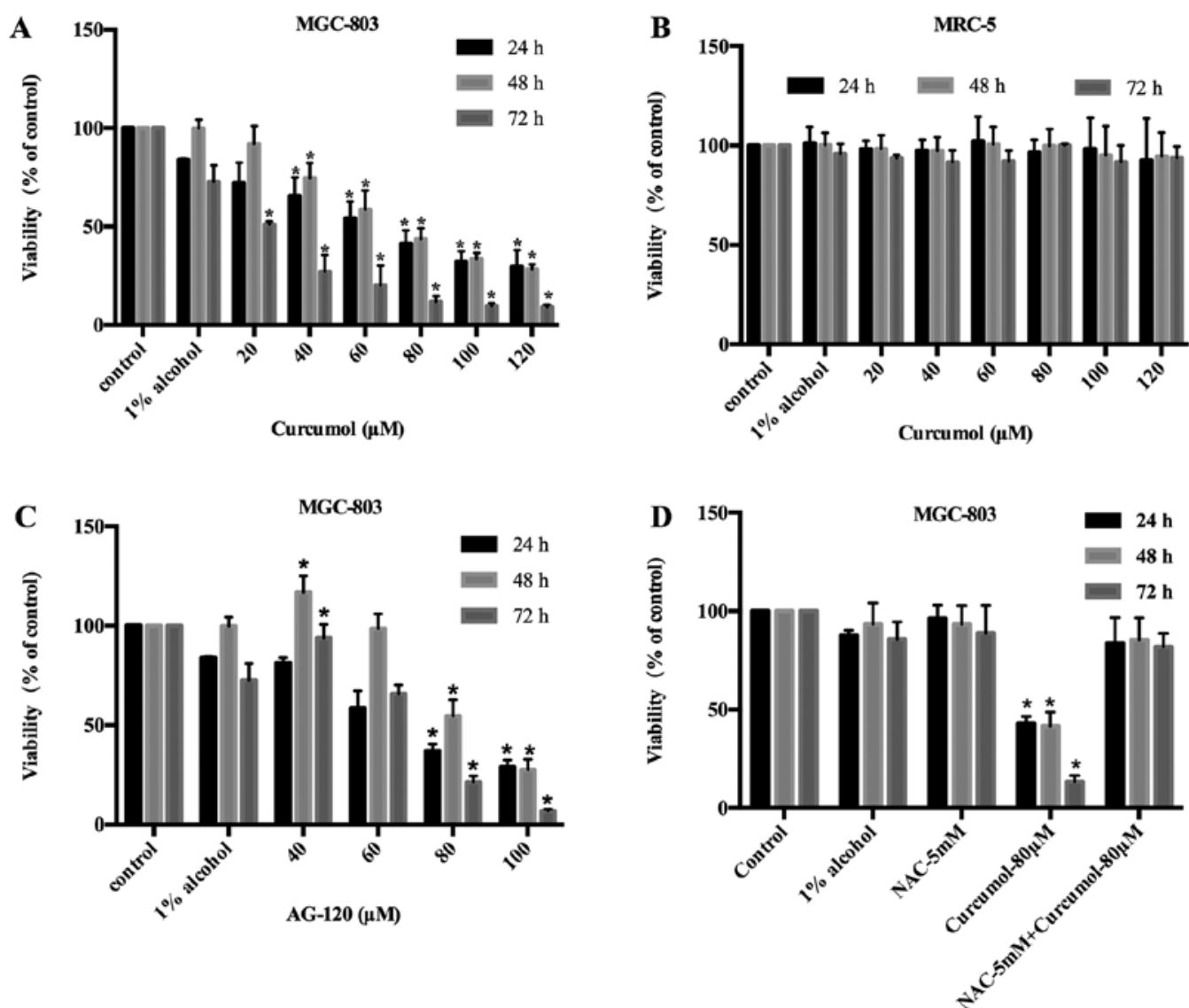

Figure 1. Curcumol inhibits the viability of GC cells MGC-803 and human embryonic lung fibroblast cells MRC-5. (A and B) MGC-803 and MRC-5 cells were treated with the control (DMEM culture), $1 \%$ alcohol (DMEM culture medium with $1 \%$ alcohol) and curcumol (20,40,60, 80, 100 and $120 \mu \mathrm{M})$ for 24 48 or 72 h. (C) MGC-803 cells were treated with the control (DMEM culture), 1\% alcohol (DMEM culture medium with 1\% alcohol) and AG-120 (40, 60, 80 and $100 \mu \mathrm{M}$ ) for 24, 48 or $72 \mathrm{~h}$. (D) MGC-803 cells were treated with the control (DMEM culture), $1 \%$ alcohol (DMEM culture medium with $1 \%$ alcohol), curcumol $(80 \mu \mathrm{M})$, NAC $(5 \mathrm{mM})$, curcumol $(80 \mu \mathrm{M})+\mathrm{NAC}(5 \mathrm{mM})$ for 24,48 and $72 \mathrm{~h}$. The MTT assay was performed to determine cell viability and values are expressed as the mean \pm SD of three separate experiments. " $p<0.05$ vs. control. GC, gastric cancer.

transferred to polyvinylidene fluoride (PVDF) membranes. Next the membranes were blocked with 5\% skim milk for $1 \mathrm{~h}$ at room temperature. Subsequently, the membranes were washed in TBST and incubated with antibodies of GAPDH (1:1,000 dilution), IDH1 (1:5,000 dilution) and IDH2 (1:2,500 dilution) overnight at $4^{\circ} \mathrm{C}$. On the second day, the membranes were washed in TBST and then incubated at room temperature for $1 \mathrm{~h}$ with the appropriate secondary antibody (goat anti-mouse $\mathrm{IgG}$ for GAPDH and goat anti-rabbit $\operatorname{IgG}$ for IDH1 and IDH2). The bands were visualized using an enhanced chemiluminescence (ECL) system (Thermo Fisher Scientific) and Kodak XBT-1 film. Gray value analysis was performed using ImageJ software (National Institute of Mental Health, Bethesda, MD, USA). The variation in the gray value was expressed as fold changes compared to the control in the blot.

$R T-q P C R$. Total RNA was isolated from the MGC- 803 cells treated with curcumol $(0,20,40,60$ and $80 \mu \mathrm{M})$ using the RNAiso Plus. The AG-120-treated cells $(80 \mu \mathrm{M})$ were used as a positive control.

After incubation at $45^{\circ} \mathrm{C}$ for $2 \mathrm{~min}$, genomic DNA was removed in the reaction with a total volume of $10 \mu$ l consisting of $2 \mu \mathrm{lgDNA}$ eraser buffer, $1 \mu \mathrm{lgDNA}$ eraser, an appropriate amount of RNA (up to $1 \mu \mathrm{g}$ ) and nuclease-free water. cDNA was synthesized in the reaction with a total volume of $20 \mu \mathrm{l}$ consisting of $10 \mu \mathrm{l}$ of the reaction liquid of the last step, $4 \mu \mathrm{l}$ PrimeScript buffer, $1 \mu \mathrm{l}$ reverse transcriptase, $1 \mu \mathrm{l}$ RT Primer Mix and $4 \mu \mathrm{l}$ nuclease-free water. The reaction conditions included $37^{\circ} \mathrm{C}$ for $15 \mathrm{~min}$, followed by $85^{\circ} \mathrm{C}$ at $50 \mathrm{sec}$ and ending at $4^{\circ} \mathrm{C}$. Real-time RT-PCR was performed using the Thermal Cycler Real-Time system (Thermo Fisher Scientific). The reaction was performed at a final volume of $10 \mu 1$ containing $5 \mu 1$ SYBR Premix Ex Taq II, $1 \mu \mathrm{l}$ of appropriate primer $(10 \mu \mathrm{M})$, $1 \mu \mathrm{l}$ cDNA $(50 \mathrm{ng} / \mu \mathrm{l})$ and nuclease-free water. The cycling conditions included one cycle at $95^{\circ} \mathrm{C}$ for $30 \mathrm{sec}$, followed by 40 cycles of $5 \mathrm{sec}$ at $95^{\circ} \mathrm{C}$ and $20 \mathrm{sec}$ at $60^{\circ} \mathrm{C}$. The sequences of the primers were as follows: GAPDH forward, 5'-CAGGA GGCATTGCTGATGAT-3' and reverse, 5'-CAGGAGGCAT TGCTGATGAT-3'; IDH1 forward, 5'-ACTTGCACATGA CTGGAACG-3' and reverse, 5'-TCCTGCGGCCTAAAC AGTAT-3'; IDH2 forward, 5'-AGAGTGGAGCCATGACC AAG-3' and reverse, 5'-TGTCCAGGTTGCTCTTGATG-3'.

Statistical analysis. All of the data are presented as the mean \pm standard deviation (SD). The rate of survival and the $\mathrm{IC}_{50}$ values were analyzed by GraphPad Prism 6.0 (GraphPad Software Inc.). A two-tailed independent sample t-test was used to assess the level of significance between the means. A P-value of $<0.05$ was considered to indicate a statistically significant difference. 


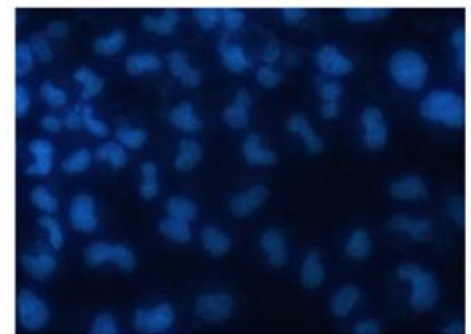

Control

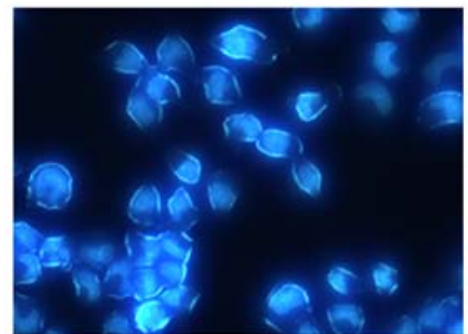

Curcumol-60 $\mu \mathrm{M}$

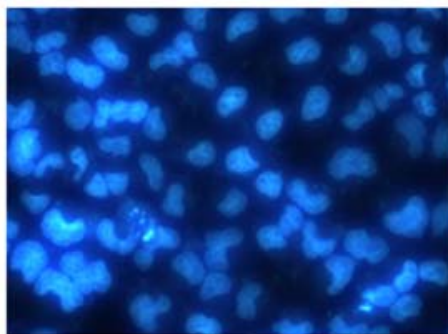

Curcumol-20 $\mu \mathrm{M}$

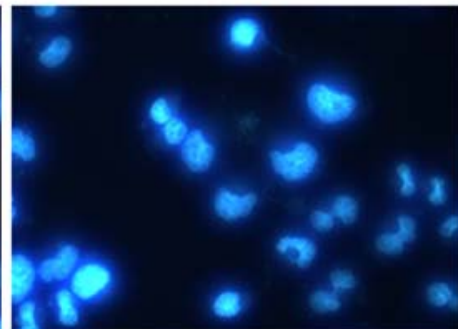

Curcumol-80 $\mu \mathrm{M}$

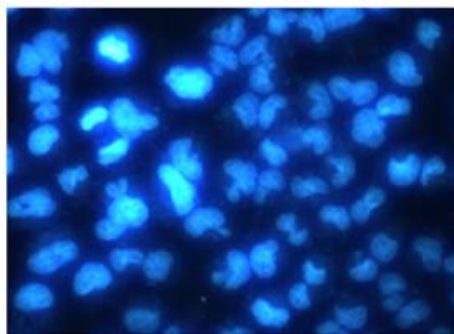

Curcumol-40 $\mu \mathrm{M}$

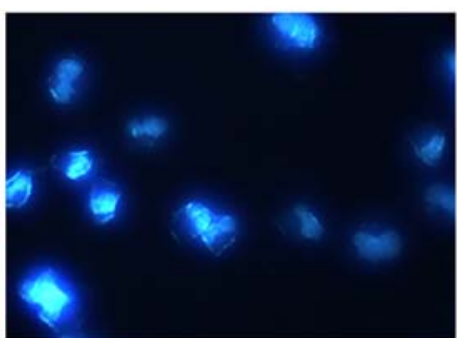

Curcumol-100 $\mu \mathrm{M}$

Figure 2. Morphology of MGC-803 cells after $24 \mathrm{~h}$ of incubation with curcumol at concentrations of 0, 20, 40, 60, 80 and $100 \mu \mathrm{M}$. The cells were stained with Hoechst 33258 and observed on a fluorescence microscope (magnification, $\mathrm{x} 400$ ).

\section{Results}

Anti-proliferative activities of curcumol in MGC-803 cells. Human embryonic lung fibroblast MRC-5 cells treated with curcumol as a control exhibited light toxicity. AG-120 which is an inhibitor of IDH1, was used as a positive control in MGC-803 cells. Curcumol inhibited the viability of MGC-803 cells with an $\mathrm{IC}_{50}$ value of $114.60 \pm 3.55 \mu \mathrm{M}$ at $24 \mathrm{~h}, 66.36 \pm 1.26 \mu \mathrm{M}$ at $48 \mathrm{~h}$ and $29.00 \pm 1.14 \mu \mathrm{M}$ at $72 \mathrm{~h}$. The viability of MGC-803 cells was suppressed by curcumol in a time- and concentration-dependent manner (Fig. 1A). Fig. 1B revealed that curcumol was slightly effective on MRC-5 cells, thus signifying that curcumol has light toxicity on non-tumor cells. AG-120 inhibited the viability of MGC-803 cells with an $\mathrm{IC}_{50}$ value of $58.19 \pm 1.14 \mu \mathrm{M}$ at $24 \mathrm{~h}, 75.40 \pm 1.04 \mu \mathrm{M}$ at $48 \mathrm{~h}$ and $67.24 \pm 1.14 \mu \mathrm{M}$ at $72 \mathrm{~h}$. As time progressed, the antitumor effect of curcumol improved compared to the AG-120 treatment. This group demonstrated that the MGC-803 cells were also suppressed by AG-120, however the potency was lower than that of curcumol at low concentrations (Fig. 1C). In addition, NAC was capable of reversing the inhibitory effect of curcumol on cell proliferation (Fig. 1D).

Curcumol induces apoptosis of MGC-803 cells. To assess the level of apoptosis in the MGC-803 cells treated with curcumol, we performed Hoechst 33258 fluorescence staining following curcumol treatment. The apoptotic morphological changes of MGC-803 cells treated with curcumol for $24 \mathrm{~h}$ were observed and compared to those of the control cells treated with DMEM and 1\% ethyl alcohol. Curcumol at 40, 60, 80 and $100 \mu \mathrm{M}$ induced significant morphological changes in the MGC-803 cells, including a decrease in cell volume, intercellular junction disappearance and formation of apoptotic bodies (Fig. 2). Annexin V-FITC/PI double staining followed by FACS analysis confirmed the dose-dependent

\section{$\mathbf{A}$}
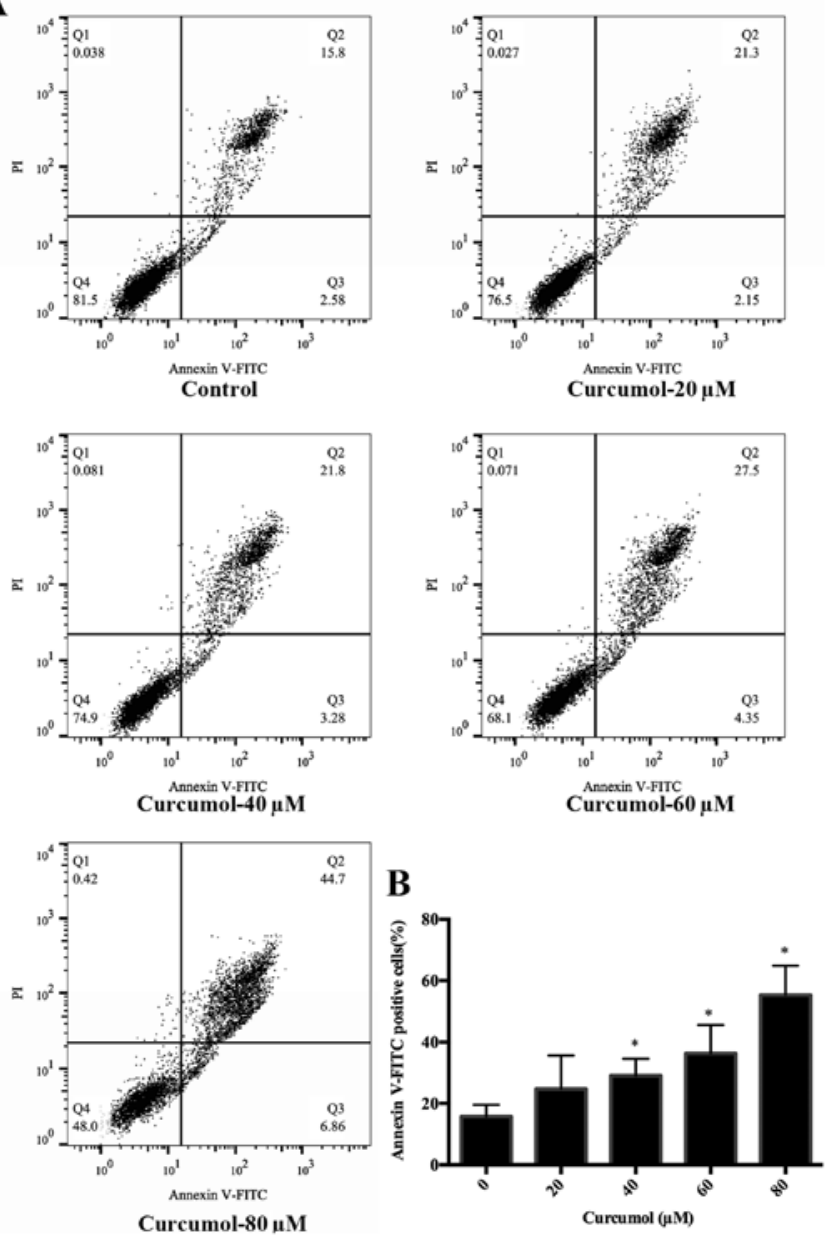

Figure 3. Curcumol induces apoptosis of MGC-803 cells treated with curcumol $(0,20,40,60$ and $80 \mu \mathrm{M})$ for $24 \mathrm{~h}$. (A) The cells were stained using Annexin V-FITC and PI, and then analyzed by flow cytometry. (B) The results are reported in the histogram. Data represent the means $\pm \mathrm{SD}$ of three independent experiments. ${ }^{*}$ p $<0.05$ vs. control. 
A

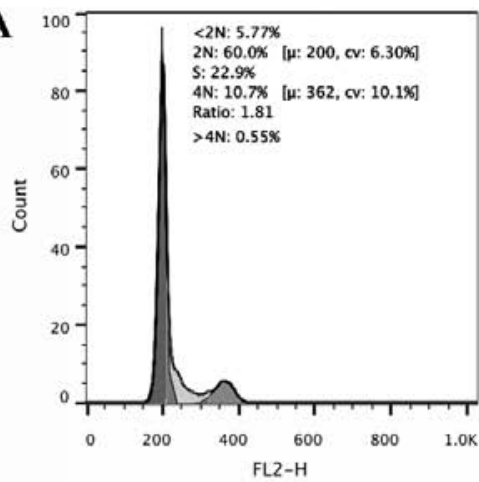

Control

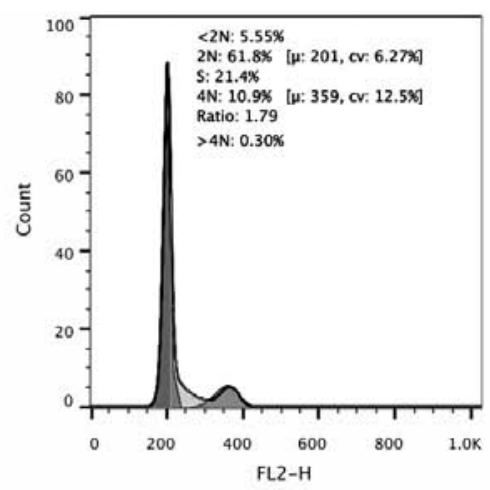

Curcumol-20 $\mu \mathrm{M}$

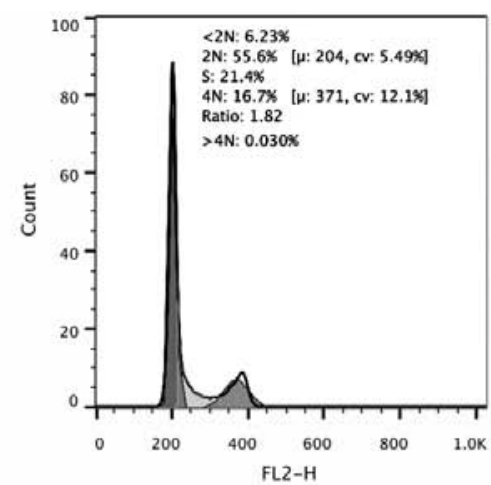

Curcumol-40 $\mu \mathrm{M}$

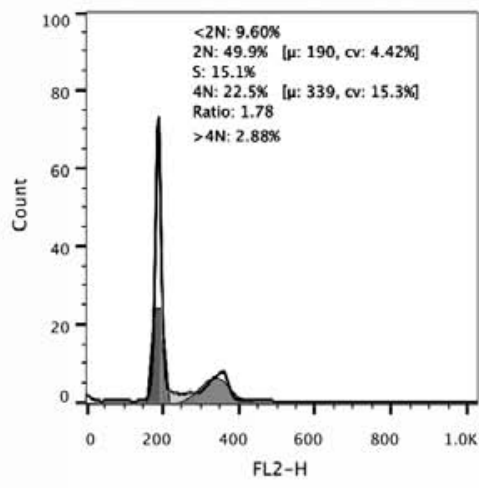

Curcumol-60 $\mu \mathrm{M}$

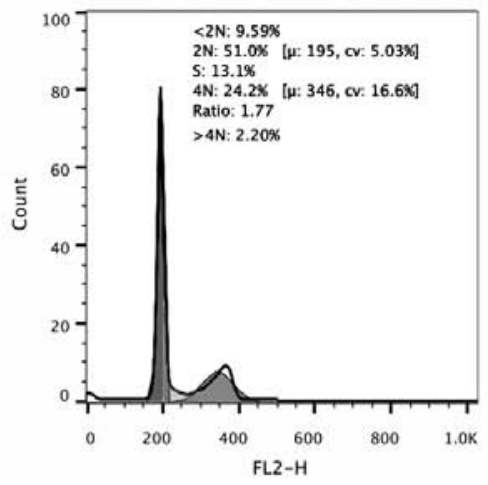

Curcumol-80 $\mu \mathrm{M}$
B

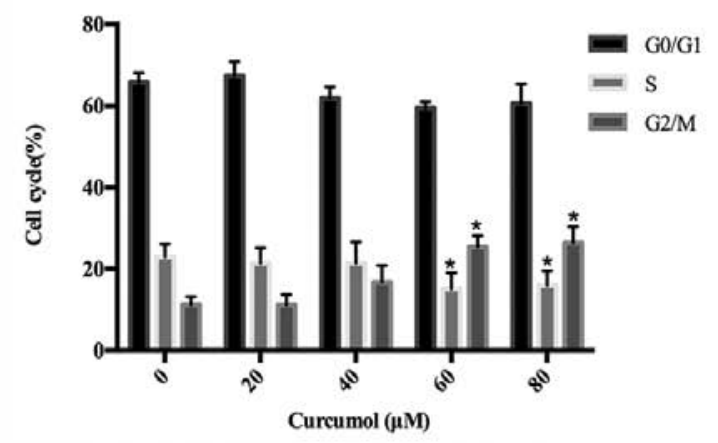

Figure 4. (A) Flow cytometric analysis using PI staining to detect the cell cycle distribution of MGC-803 cells after 24 h of culture with curcumol at $0,40,60$ and $80 \mu \mathrm{M}$. (B) The results are reported in the diagram. Data represent the means \pm SD of three separate experiments. ${ }^{*}$ p $<0.05$ vs. control.

apoptosis-inducing effect of curcumol. The results revealed a dose-dependent increase in the apoptosis rate for cells treated with 40,60 and $80 \mu \mathrm{M}$ of curcumol compared to the control cells (Fig. 3).

Curcumol induces cell cycle arrest at the G2/M phase of MGC-803 cells. After curcumol was confirmed to inhibit MGC-803 cell growth, we next examined whether the growth inhibitory effect of curcumol was related to cell cycle arrest. PI staining followed by FACS analysis demonstrated the effect of curcumol on cell cycle progression in MGC-803 cells. MGC-803 cells treated with curcumol at 60 and $80 \mu \mathrm{M}$ resulted in a small accumulation of cells in the G2/M phase and a decrease in the $\mathrm{S}$-phase cell population. This result revealed a $\mathrm{G} 2 / \mathrm{M}$ phase cell cycle arrest of gastric cells upon exposure to curcumol (Fig. 4). However the cycle arrest of curcumol was not statistically significant.

Curcumol decreases the MMP of MGC-803 cells. An MMP decrease is an early manifestation of apoptosis. As an additional verification of the effects of curcumol, we evaluated the MMP of MGC-803 cells after $24 \mathrm{~h}$ of curcumol treatment. Most of the negative control cells were stained red by JC-1, indicating an intact mitochondrial membrane. In contrast, cells treated with curcumol exhibited increasing amounts of green fluorescence. The effect was more obvious with
80- $\mu \mathrm{M}$ treatment. Analysis of the red/green fluorescence light density ratio revealed that the decrease was dose-dependent and significant for the 40,60 and $80 \mu \mathrm{M}$ concentrations of curcumol. CCCP-treated cells were used as a positive control (Fig. 5).

Curcumol increases the levels of ROS in MGC-803 cells. It has been confirmed that excess ROS promotes cell death and curcumol upregulates ROS to induce apoptosis in tumors (16). Thus, we further examined the effects of curcumol on ROS production in MGC-803 cells. The level of ROS in the MGC-803 cells was assessed using the DCFH-DA probe and flow cytometry in the FL1-H channel (Fig. 6A). The result revealed that the level of ROS increased significantly after treatment with curcumol for $24 \mathrm{~h}$ at concentrations of 60 or $80 \mu \mathrm{M}(\mathrm{p}<0.05)$. NAC was capable of decreasing the increase in ROS caused by curcumol. Rosup treated cells were used as a positive control (Fig. 6B).

Curcumol downregulates IDH1 expression. Our previous research revealed that curcumol increased the levels of ROS to promote cell death. However a study demonstrated that IDH1-dependent reductive carboxylation mitigated the intracellular ROS level and protected tumor cells from ROS damage. In order to explore the molecular mechanism through which curcumol inhibits cell proliferation, the expression levels of IDH1 and IDH2 were 

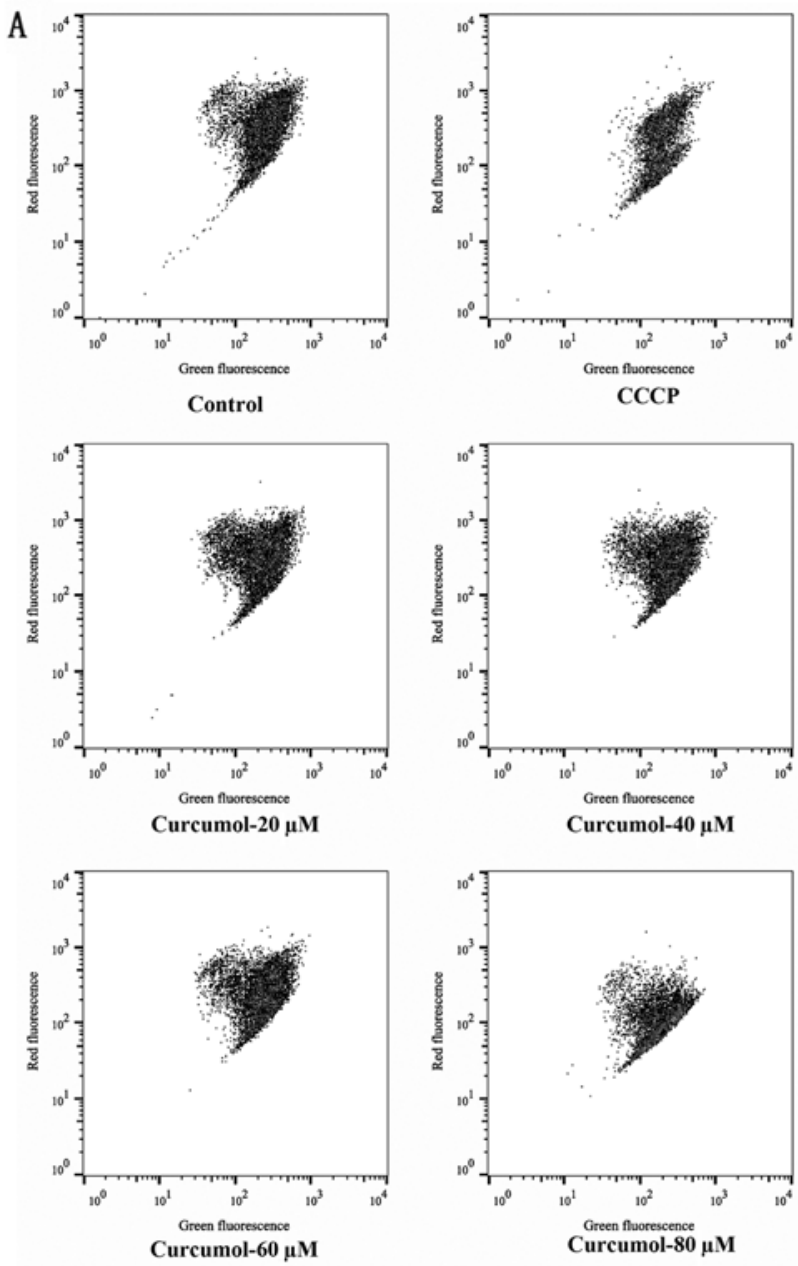

B

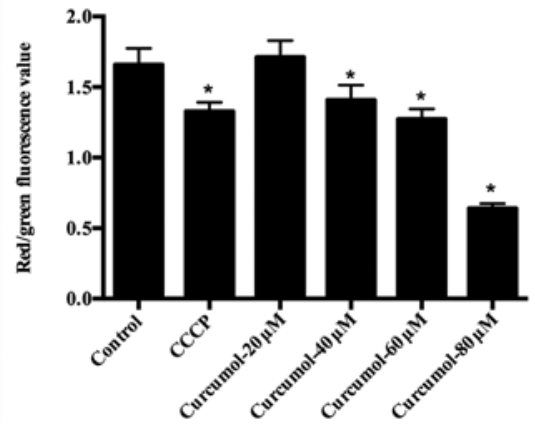

Figure 5. (A) The cells were stained by JC-1 working solution after MGC-803 cells were exposed to curcumol $(0,20,40,60$ and $80 \mu \mathrm{M})$ for $24 \mathrm{~h}$, and the MMP was analyzed by flow cytometry. (B) The results are reported in the histogram. Data represent the means $\pm \mathrm{SD}$ of three independent experiments. " $\mathrm{p}<0.05$ vs. the control group. CCCP is a positive control provided by the kit. MMP, mitochondrial membrane potential.

determined by western blotting. The expression levels of IDH1 were downregulated after cells were treated with 60 or $80 \mu \mathrm{M}$ of curcumol, but the expression levels of IDH2 were not altered by curcumol. AG-120 $(80 \mu \mathrm{M})$ treatment was used as a positive control (Fig. 7). The result of RT-qPCR confirmed the same tendency in the gene expression of IDH1 and IDH2. In contrast to the negative control group, the expression level of IDH1 was significantly decreased after $48 \mathrm{~h}$ of treatment with curcumol at 40,60 and $80 \mu \mathrm{M}$ (Fig. 8). The results may reveal a new molecular mechanism in gastric cell apoptosis induced by curcumol.

\section{Discussion}

Previous studies have demonstrated that the extract of Radix Curcumae and curcumol derivatives were effective against various types of cancer (12,16-19). However, research on curcumol was limited, especially considering its antiproliferation mechanism in GC. In the present study, we found that curcumol suppressed the proliferation of GC MGC-803 cells in a dose-dependent manner, however slight toxicity was observed in the non-tumor cells. Although, it would have been preferable to use normal gastric cells as a control to reflect the selectivity of curcumol to GC cells, due to laboratory conditions, we could only use MRC-5 cells as a normal cell control. The human embryonic lung fibroblast MRC-5 cell line is considered to be representative of normal human cells. It is derived from normal lung tissue of a 14-week-old male fetus. Both fibroblasts and gastric smooth muscle cells were differentiated from the embryonic mesoderm. MRC-5 cells are often used to test the toxicity of drugs on normal cells (20). Not only normal lung cells but also other normal cells that were differentiated from the embryonic mesoderm could use MRC- 5 cells as a control to detect the toxicity of normal cells treated by curcumol.

Furthermore, the induction of apoptosis in human GC MGC-803 cells treated with curcumol was also assessed using H33258 staining, Annexin V/PI double staining and MMP assay. This induction may be related to the downregulation of IDH1 by curcumol. AG-120 is an orally available inhibitor of IDH1 with potential antineoplastic activity. After observation that curcumol had an inhibitory effect on IDH1, we compared the inhibitory effects of AG-120 and curcumol on MGC-803 cells. The results revealed that the antitumor effect of curcumol was superior to that of AG-120, suggesting that curcumol may still have other anticancer targets.

For the past few years, accumulating targeted molecules that may be used for the treatment of GC have been discovered, including HER2, vascular endothelial growth factor (VEGF) (21), phosphofructokinase-2/fructose-2,6-bisphosphatase 3 (PFKFB3, one of the glycolytic enzymes) (22), the nuclear factor- $\kappa \mathrm{B}(\mathrm{NF}-\kappa \mathrm{B})$ signaling pathway (23), Wnt signaling (24), cyclooxygenase-2 (COX-2) and prostaglandin $\mathrm{E}_{2}\left(\mathrm{PGE}_{2}\right)(25)$. However these targeted molecules are only suitable for certain GC patients. Thus, it is essential to explore new targets.

Increasing evidence has revealed that inducing cancer cell apoptosis is an effective way to treat tumors (5). Previously, ROS was regarded as a cause in the induction and promotion of cancer $(26,27)$. However a study revealed that mitochondrial ROS induces apoptosis through the intrinsic pathway (28). Moreover, there are numerous studies demonstrating that drugs induce apoptosis along with the loss of MMP and the increase of ROS generation (29-38). Furthermore, in recent years photodynamic therapy (PDT) is characterized by generation of ROS to treat cancer via the cell apoptotic pathway $(39,40)$. In the present study, we also demonstrated that curcumol treatment decreased MMP levels and increased ROS levels in the cells. NAC is a commonly used ROS inhibitor and the ROS assay results revealed that it could antagonize the increase of ROS induced by curcumol. An MTT assay revealed that NAC could decrease the inhibitory effect of MGC-803 cells induced by curcumol, thus 

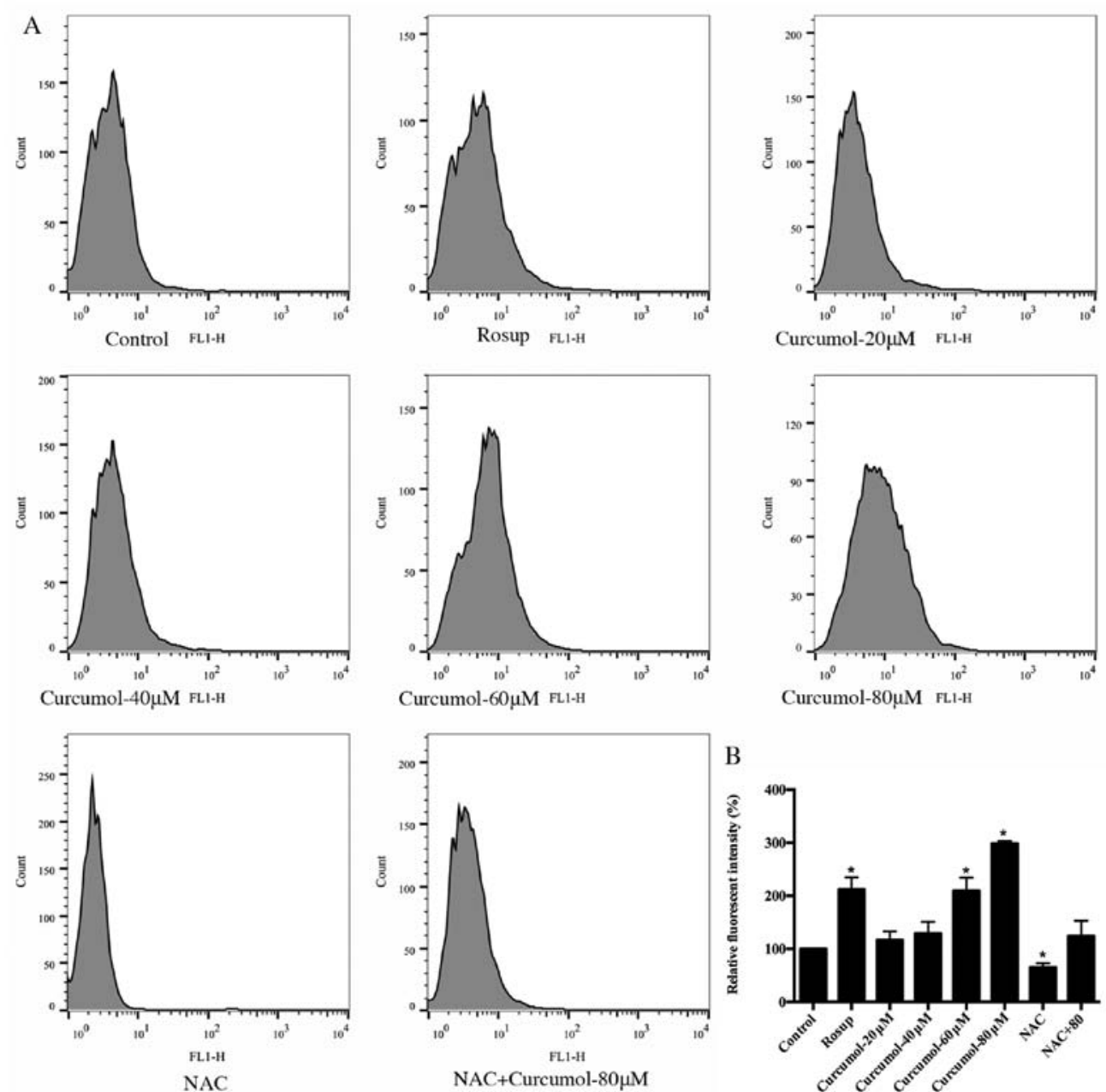

Figure 6. (A) The cells were loaded with DCFH-DA after MGC-803 cells were treated with curcumol $(0,20,40,60$ and $80 \mu \mathrm{M})$ for $24 \mathrm{~h}$ and the level of ROS was analyzed by flow cytometry. (B) The data are the statistical results of three experiments and reported in the histogram. Data represent the means \pm SD and " $\mathrm{p}<0.05$ vs. the control group. Rosup is a positive control provided by the kit. ROS, reactive oxygen species.

A

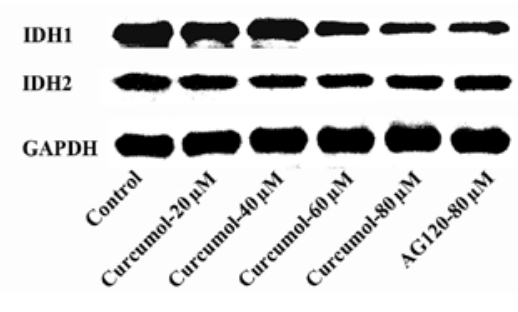

B

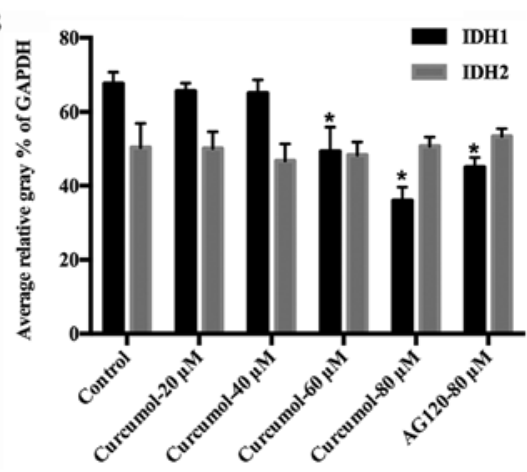

Figure 7. (A) Levels of IDH1 and IDH2 in MGC-803 cells are modulated by curcumol $(0,20,40,60$ and $80 \mu \mathrm{M})$ and AG-120 $(80 \mu \mathrm{M})$ for $48 \mathrm{~h}$. (B) The means \pm SD grey value of the western blot analysis bands are statistical results of three independent experiments in the histogram. ${ }^{*} \mathrm{p}<0.05$ vs. the control group.

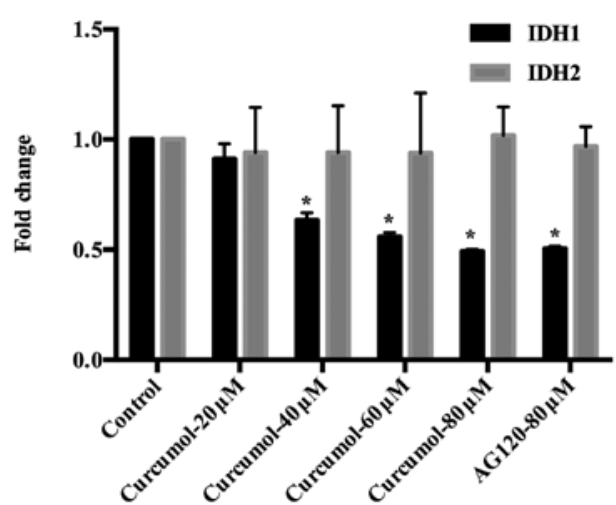

Figure 8. Relative RNA expression of IDH1 and IDH2 in the MGC-803 cell line following curcumol treatment with concentrations of $0,20,40,60$ and $80 \mu \mathrm{M}$ for $48 \mathrm{~h}$. The last treatment group was the AG-120 $(80 \mu \mathrm{M})$. The experiment was repeated three times. ${ }^{*} \mathrm{p}<0.05$ vs. the control group.

suggesting that curcumol may also play a role in inhibiting the proliferation of MGC-803 cells by increasing intracellular ROS.

The isocitrate dehydrogenase (IDH) family is comprised of key functional metabolic enzymes in the Krebs cycle that catalyze the conversion of isocitrate to $\alpha$-ketoglutarate 
$(\alpha-K G)(41)$. It is harmful to malignant cells when intracellular ROS increases. However an IDH1-dependent reductive carboxylation mitigated intracellular ROS levels and protected cancer cells from ROS damage. Both IDH1 in the cytosol and IDH2 in the mitochondria are necessary, as deletion of either enhances ROS generation in mitochondria and inhibits cell proliferation (42). A study demonstrating that downregulation of IDH2 and TET family enzymes was likely one of the mechanisms underlying 5-hmC loss in melanoma (43). In addition, the level of IDH2 in GC MGC-803 cells was significantly lower than that in adjacent normal tissues (41).

Therefore, IDH1 and IDH2 expression in the GC MGC-803 cells was evaluated using western blotting and RT-qPCR in our study. The results revealed that the IDH1 expression level was lower in curcumol-treated cells compared with the control cells treated by DMEM with $1 \%$ ethyl alcohol in the GC MGC-803 cells. However the IDH2 expression level was not altered. Curcumol inhibited GC MGC-803 cell proliferation by downregulating IDH1, which enhanced intracellular ROS.

AG-120 as an inhibitor of IDH1, was reported to have a promising effect at the initial treatment of acute myelogenous leukemia (AML) patients harboring IDH1 mutant in a phase I clinical trial (44). Our results demonstrated that AG-120 suppressed proliferation of GC MGC-803 cells, however less efficiently than curcumol.

The Curcuma extract exhibited anticancer activity in GC as was reported by Shi et al (45) who drew the conclusion that zedoary oil inhibited AGS and MGC-803 cell proliferation. In addition, they also found that zedoary oil inhibited AGS cells through cell cycle arrest and cell apoptosis promotion. Furthermore, they demonstrated that low concentrations of zedoary oil were less inhibitory toward normal gastric epithelial GES-1 cells. Their research was very detailed and it helped us with our research on curcumol. A single component and a clear structure is the future direction of new drug research and development. Curcumol is a component of zedoary oil. Based on the research on zedoary oil, we explored the pharmacodynamics and mechanism of curcumol in MGC-803 cells, and provided some new evidence for the development of a new drug.

To summarize, curcumol not only inhibited the proliferation but also increased the intracellular ROS level in MGC-803 cells. In addition this may be the way that curcumol affected cell apoptosis in MGC-803 cells. Moreover, there is some evidence demonstrating that the cell cycle arrest in the G2/M phase and the decrease of MMP was induced by curcumol in MGC-803 cells. IDH1 may be a promising target to treat GC in the future. In conclusion, curcumol may be a potential drug used in the treatment of GC with multiple targets. The study of the curcumol mechanism in cancer treatment will offer new targets, which may be helpful in the development of new antineoplastic drugs.

\section{Acknowledgements}

This study was supported by the Science and Technology Planning Project of Guangdong Province, China (no. 2015A020211028). We would like to thank Dr Min Wei for the critical reading and the editing of the manuscript.

\section{References}

1. Torre LA, Bray F, Siegel RL, Ferlay J,Lortet-Tieulent J and Jemal A: Global cancer statistics, 2012. CA Cancer J Clin 65: 87-108, 2015.

2. Hudler P: Challenges of deciphering gastric cancer heterogeneity. World J Gastroenterol 21: 10510-10527, 2015.

3. Chen W, Zheng R, Baade PD, Zhang S, Zeng H, Bray F, Jemal A, Yu XQ and He J: Cancer statistics in China, 2015. CA Cancer J Clin 66: 115-132, 2016.

4. Xu W, Yang Z and Lu N: Molecular targeted therapy for the treatment of gastric cancer. J Exp Clin Cancer Res 35: 1, 2016.

5. Ko YC, Lien JC, Liu HC, Hsu SC, Ji BC, Yang MD, Hsu WH and Chung JG: Demethoxycurcumin induces the apoptosis of human lung cancer NCI-H460 cells through the mitochondrial-dependent pathway. Oncol Rep 33: 2429-2437, 2015.

6. Gomez-Martín C, Lopez-Rios F, Aparicio J, Barriuso J, García-Carbonero R, Pazo R, Rivera F, Salgado M, Salud A, Vázquez-Sequeiros E, et al: A critical review of HER2-positive gastric cancer evaluation and treatment: From trastuzumab, and beyond. Cancer Lett 351: 30-40, 2014.

7. Al-Batran SE, Ducreux M and Ohtsu A: mTOR as a therapeutic target in patients with gastric cancer. Int J Cancer 130: 491-496, 2012.

8. Zhang K, Cui J, Xi H, Bian S, Ma L, Shen W, Li J, Wang N, Wei B and Chen L: Serum HER2 is a potential surrogate for tissue HER2 status in gastric cancer: A systematic review and meta-analysis. PLoS One 10: e0136322, 2015.

9. Liu JS, He SC, Zhang ZL, Chen R, Fan L, Qiu GL, Chang S, Li L and Che XM: Anticancer effects of $\beta$-elemene in gastric cancer cells and its potential underlying proteins: A proteomic study. Oncol Rep 32: 2635-2647, 2014.

10. Cai XZ, Huang WY, Qiao Y, Du SY, Chen Y, Chen D, Yu S, Che RC, Liu N, Jiang Y: Inhibitory effects of curcumin on gastric cancer cells: A proteomic study of molecular targets. Phytomedicine 20: 495-505, 2013

11. Cai LJ, Song SP, Lu B and Meng LN: Reversal effect of curcuma wenyujin extract on SGC-7901/VCR induced subcutaneous transplanted tumor in nude mice and its effect on the expression of P-glycoprotein. Zhongguo Zhong Xi Yi Jie He Za Zhi 34: 1347-1353, 2014 (In Chinese).

12. Guo P, Wang YW, Weng BX, Li XK, Yang SL and Ye FQ: Synthesis, anti-tumor activity, and structure-activity relationships of curcumol derivatives. J Asian Nat Prod Res 16: 53-58, 2014.

13. Tang QL, Guo JQ, Wang QY, Lin HS, Yang ZP, Peng T, Pan XD, Liu B, Wang SJ and Zang LQ: Curcumol induces apoptosis in SPC-A-1 human lung adenocarcinoma cells and displays antineoplastic effects in tumor bearing mice. Asian Pac J Cancer Prev 16: 2307-2312, 2015.

14. Gao C, Ding Z, Liang B, Chen N and Cheng D: Study on the effects of curcumin on angiogenesis. Zhong Yao Cai 26: 499-502, 2003 (In Chinese).

15. Lu JJ, Dang YY, Huang M, Xu WS, Chen XP and Wang YT: Anti-cancer properties of terpenoids isolated from Rhizoma Curcumae - a review. J Ethnopharmacol 143: 406-411, 2012.

16. Abdullah Thani NA, Sallis B, Nuttall R, Schubert FR, Ahsan M, Davies D, Purewal S, Cooper A and Rooprai HK: Induction of apoptosis and reduction of MMP gene expression in the U373 cell line by polyphenolics in Aronia melanocarpa and by curcumin. Oncol Rep 28: 1435-1442, 2012.

17. Fan H, Liang Y, Jiang B, Li X, Xun H, Sun J, He W, Lau HT and Ma X: Curcumin inhibits intracellular fatty acid synthase and induces apoptosis in human breast cancer MDA-MB-231 cells. Oncol Rep 35: 2651-2656, 2016.

18. Du Q, Hu B, An HM, Shen KP, Xu L, Deng S and Wei MM: Synergistic anticancer effects of curcumin and resveratrol in Hepa1-6 hepatocellular carcinoma cells. Oncol Rep 29: 1851-1858, 2013.

19. Zhao G, Han X, Zheng S, Li Z, Sha Y, Ni J, Sun Z, Qiao S and Song Z: Curcumin induces autophagy, inhibits proliferation and invasion by downregulating AKT/mTOR signaling pathway in human melanoma cells. Oncol Rep 35: 1065-1074, 2016.

20. Park EH, Bae WY, Eom SJ, Kim KT and Paik HD: Improved antioxidative and cytotoxic activities of chamomile (Matricaria chamomilla) florets fermented by Lactobacillus plantarum KCCM 11613P. J Zhejiang Univ Sci B 18: 152-160, 2017.

21. Narita Y and Muro K: Challenges in molecular targeted therapy for gastric cancer: Considerations for efficacy and safety. Expert Opin Drug Saf 16: 319-327, 2016. 
22. Han J, Meng Q, Xi Q, Wang H and Wu G: PFKFB3 was overexpressed in gastric cancer patients and promoted the proliferation and migration of gastric cancer cells. Cancer Biomark 18: 249-256, 2017.

23. Kang Y, Hu W, Bai E, Zheng H, Liu Z, Wu J, Jin R, Zhao C and Liang G: Curcumin sensitizes human gastric cancer cells to 5-fluorouracil through inhibition of the NFkB survival-signaling pathway. Onco Targets Ther 9: 7373-7384, 2016.

24. Guo X, Zhang L, Fan Y, Zhang D, Qin L, Dong S and Li G: Oxysterol binding protein-related protein 8 inhibits gastric cancer growth through induction of ER stress, inhibition of Wnt signaling and activation of apoptosis. Oncol Res 25: 799-808, 2017.

25. Echizen K, Hirose O, Maeda Y and Oshima M: Inflammation in gastric cancer: Interplay of the COX-2/prostaglandin $\mathrm{E}_{2}$ and Toll-like receptor/MyD88 pathways. Cancer Sci 107: 391-397, 2016.

26. DeNicola GM, Karreth FA, Humpton TJ, Gopinathan A, Wei C, Frese K, Mangal D, Yu KH, Yeo CJ, Calhoun ES, et al: Oncogeneinduced Nrf2 transcription promotes ROS detoxification and tumorigenesis. Nature 475: 106-109, 2011.

27. Ishikawa $\mathrm{K}$, Takenaga $\mathrm{K}$, Akimoto $\mathrm{M}$, Koshikawa $\mathrm{N}$, Yamaguchi A, Imanishi H, Nakada K, Honma Y and Hayashi J: ROS-generating mitochondrial DNA mutations can regulate tumor cell metastasis. Science 320: 661-664, 2008.

28. Yee C, Yang W and Hekimi S: The intrinsic apoptosis pathway mediates the pro-longevity response to mitochondrial ROS in C. elegans. Cell 157: 897-909, 2014.

29. Zhao X, Xu L, Zheng L, Yin L, Qi Y, Han X, Xu Y and Peng J: Potent effects of dioscin against gastric cancer in vitro and in vivo. Phytomedicine 23: 274-282, 2016.

30. Wang SQ, Wang C, Wang JW, Yang DX, Wang R, Wang CJ, Li HJ, Shi HG, Ke Y and Liu HM: Geridonin, a novel derivative of oridonin, inhibits proliferation of MGC 803 cells both in vitro and in vivo through elevating the intracellular ROS. J Pharm Pharmacol 69: 213-221, 2017.

31. Shi XJ, Yu B, Wang JW, Qi PP, Tang K, Huang X and Liu HM: Structurally novel steroidal spirooxindole by 241 potently inhibits tumor growth mainly through ROS-mediated mechanisms. Sci Rep 6: 31607, 2016.

32. Zhou Y, Wei L, Zhang H, Dai Q, Li Z, Yu B, Guo Q and Lu N: FV-429 induced apoptosis through ROS-mediated ERK2 nuclear translocation and p53 activation in gastric cancer cells. J Cell Biochem 116: 1624-1637, 2015.

33. Huang XC, Jin L, Wang M, Liang D, Chen ZF, Zhang Y, Pan YM and Wang HS: Design, synthesis and in vitro evaluation of nove dehydroabietic acid derivatives containing a dipeptide moiety as potential anticancer agents. Eur J Med Chem 89: 370-385, 2015.
34. Ye MY, Yao GY, Pan YM, Liao ZX, Zhang Y and Wang HS: Synthesis and antitumor activities of novel $\alpha$-aminophosphonate derivatives containing an alizarin moiety. Eur J Med Chem 83: 116-128, 2014.

35. Li JF, Huang RZ, Yao GY, Ye MY, Wang HS, Pan YM and Xiao JT: Synthesis and biological evaluation of novel anilinederived asiatic acid derivatives as potential anticancer agents. Eur J Med Chem 86: 175-188, 2014.

36. Zhou Y, Tian L, Long L, Quan M, Liu F and Cao J: Casticin potentiates TRAIL-induced apoptosis of gastric cancer cells through endoplasmic reticulum stress. PLoS One 8: e58855, 2013.

37. Wu C, Wang C, Han T, Zhou X, Guo S and Zhang J: Insight into the cellular internalization and cytotoxicity of graphene quantum dots. Adv Healthe Mater 2: 1613-1619, 2013.

38. Qian X, Li J, Ding J, Wang Z, Duan L and Hu G: Glibenclamide exerts an antitumor activity through reactive oxygen species-c-jun NH2-terminal kinase pathway in human gastric cancer cell line MGC-803. Biochem Pharmacol 76: 1705-1715, 2008.

39. Chen CW, Chan YC, Hsiao M and Liu RS: Plasmon-enhanced photodynamic cancer therapy by upconversion nanoparticles conjugated with Au nanorods. ACS Appl Mater Interfaces 8: 32108-32119, 2016

40. Liu L, Fu L, Jing T, Ruan Z and Yan L: pH-triggered polypeptides nanoparticles for efficient BODIPY imaging-guided near infrared photodynamic therapy. ACS Appl Mater Interfaces 8: 8980-8990, 2016

41. Chou NH, Tsai CY, Tu YT, Wang KC, Kang CH, Chang PM, Li GC, Lam HC, Liu SI and Tsai KW: Isocitrate dehydrogenase 2 dysfunction contributes to 5-hydroxymethylcytosine depletion in gastric cancer cells. Anticancer Res 36: 3983-3990, 2016.

42. Jiang L, Shestov AA, Swain P, Yang C, Parker SJ, Wang QA, Terada LS, Adams ND, McCabe MT, Pietrak B, et al: Reductive carboxylation supports redox homeostasis during anchorage-independent growth. Nature 532: 255-258, 2016.

43. Lian CG, Xu Y, Ceol C, Wu F, Larson A, Dresser K, Xu W, Tan L, Hu Y, Zhan Q, et al: Loss of 5-hydroxymethylcytosine is an epigenetic hallmark of melanoma. Cell 150: 1135-1146, 2012.

44. IDH1 inhibitor shows promising early results. Cancer Discov 5: 4, 2015.

45. Shi H, Tan B, Ji G, Lu L, Cao A, Shi S and Xie J: Zedoary oil (Ezhи You) inhibits proliferation of AGS cells. Chin Med 8: 13, 2013. 